Article

\title{
The Effects of Operational Structure Change on Performance after Seasoned Equity Offerings
}

\author{
Chihyoun Ahn ${ }^{1}$, Mi-Ok Kim ${ }^{2, *}$ (D) and Hyung-Rok Jung ${ }^{1}$ \\ 1 School of Management, Kyung Hee University, 26, Kyungheedae-ro, Dongdaemun-gu, Seoul 02447, Korea; \\ ahnch2013@khu.ac.kr (C.A.); jhrjhr@khu.ac.kr (H.-R.J.) \\ 2 Department of Tax Accounting, Baewha Women's University, \#2505 Jung Sim Kwan, 34 1st street, \\ Pirundaero, Jongno-gu, Seoul 03039, Korea \\ * Correspondence: 10141@baewha.ac.kr; Tel.: +82-2-399-0726
}

Received: 16 November 2017; Accepted: 26 December 2017; Published: 31 December 2017

\begin{abstract}
Sustainability is directly linked to firms' survival in competitive markets. To survive, firms need extra capital, and seasoned equity offerings (SEOs) are one sustainability strategy. Additional resources from SEOs lead to changes in firms' operational structure, which brings future sustainability. This study investigates whether there is sustainability in firms' operational structure and the effects of sustainable development on operational performance and market reaction. We measure the operational structure change of firms as three proxies: (1) the rate of increase in the number of operating segments, (2) the Berry-Herfindahl index using the ratio of sales of each operating segment out of total sales, and (3) the size of net investment in plant and equipment. Our results show that operational structure change has a statistically significant and positive correlation with long-term operating performance. In addition, there is no significant stock price response at first, but the operating performance in the next term is perceived as a favorable factor after three years. The results show that there are different responses in the stock market toward operational structure change. The empirical results confirm that firms with SEO have sustainable development in operational structure and that markets recognize firms' sustainability strategy arising from SEOs.
\end{abstract}

Keywords: seasoned equity offerings; sustainable development; cumulative abnormal return; operational structure change

\section{Introduction}

To survive, the firm needs extra capital, and seasoned equity offerings (SEOs) are one sustainability strategy. SEOs are a new equity issue by an already publicly traded company. Additional resources from SEOs lead to changes in a firm's operational structure, which makes the firm's future as a going concern sustainable. This study investigates whether there is sustainability in firms' operational structure and the effects of sustainable development on operational performance and market reaction.

Previous studies identify various causes of stock price response before and after SEOs. For example, high correlation with negative stock returns after SEOs is found for rights' issue size based on the price pressure hypothesis [1], the debt ratio by substitution hypothesis [2,3], and discretionary accrual before SEOs $[4,5]$. On the contrary, high correlation with positive stock returns before and after SEOs is found for the old shareholder forfeiture rate based on investment opportunities hypothesis [6], stock price compared to intrinsic value [7], and market price discount rate by the old shareholder interest hypothesis [8,9].

However, previous studies have conducted only partial analysis, and not comprehensive analysis, on SEOs and stock price response. In particular, there are insufficient empirical studies on long-term stock price and operating performance after SEOs. Therefore, this study investigates how operational 
structure change, in addition to the causes identified by previous studies, can explain operating performance and stock price after SEOs.

Firms attempt to change their operational structure for sustainable development with the resources they secure from SEOs. For example, they attempt corporate diversification strategies, such as new plant and equipment investments, expansion of their current fields of operation, and entry into new fields. However, considerable amounts of time and cost are required in the process of building a new operational structure. Thus, operating performance during that period is likely to be lower than that in previous periods. Furthermore, performance due to operational structure change appears after stock price formation, which results in a decline of stock price after SEOs.

This study examines whether firms with SEOs achieve sustainability from changing operational structure and whether the market recognizes firms' sustainability strategy from SEOs. There are many incentives for SEOs. Corporate sustainability is one of those incentives. The way of increasing sustainability is giving new response for new circumstances. Redesigning corporate structure could be the answer for new circumstances. That is, changing business segment, such as expansion, integration, or discontinued business is direct actions for corporate's sustainability. Suzanne et al. [10] mentioned the relation between sustainability and organizational change, but not an empirical paper. Thus, we use operational structure change as a proxy for sustainability.

This study measures the operational structure change of firms using three variables: (1) the rate of increase in the number of operating segments, (2) the Berry-Herfindahl index using the ratio of sales of each operating segment out of total sales, and (3) the size of net investment in plant and equipment. The samples consist of 286 corporations listed on the Korea Composite Stock Price Index (KOSPI) market and the Korea Securities Dealers Automated Quotations (KOSDAQ) market from 1997 to 2011 with a financial year-end at the end of December. Recently, the rights offering has emerged as a matter of concern to the government and investors because firms have chosen to issue a rights offering to overcome their financial distress.

To the best of our knowledge, the study of the relation between operational change from SEOs and operational performance has not been done in Korea so far. In addition, the prior research focuses not on the comprehensive factors but the certain factor that affects operating performance and market reaction after SEOs. Therefore, we examined the relation between operational change and operational performance and market reaction including comprehensive factors as control variables using Korean data.

Our empirical results are summarized as follows. First, we find a positive relationship between operational structure change for sustainable development and long-term operating performance. Furthermore, we find that stock prices reflect the sustainable organizational structure development as a favorable factor three years after an SEO.

The remainder of this paper is structured as follows. In Section 2, the research hypothesis is established based on previous studies about the performances and the effects of SEOs. In order to test the hypotheses, Section 3 suggests a testing model to verify the correlation between the performance of SEOs and operational structure change. In addition, the selection process is described for the samples used for the empirical analysis of this study. Section 4 presents the empirical results of this study, and Sections 5 and 6 present the discussion and conclusion, respectively, based on the overall summary and empirical results.

\section{Literature Review and Hypothesis}

Theories about SEOs presented by previous studies on the long-term decline of stock price and operating performance after SEOs can be categorized as follows. First, there is the price pressure hypothesis proposed by Scholes [11]. New stock issues bring excess supply to the market and thus occur at a low price according to a downward-sloping demand curve. An unexpected increase in stock supply results in a fall of the stock price in the long run, and the decline is proportional to the size of the rights issue. Asquith and Mullins [1] support the price pressure hypothesis by proving that 
the fall of stock price on the day of SEO announcement and the size of SEOs are positively correlated. However, Masulis and Korwar [3] and Bhagat and Frost [2] present contrary results, casting doubt on this hypothesis. Meanwhile, Kang [12] claims that, during economic depression, the quantity of stocks from rights issues caused a great burden and encouraged the stock price to fall.

The second category is the substitution hypothesis proposed by Galai and Masulis [13]. If the debt ratio is decreased by SEOs, existing creditors receive higher debt at lower risk. Therefore, this transfers the wealth of existing shareholders to creditors, thereby resulting in a fall of the stock price. Masulis and Korwar [3] claim that the stock price due to SEOs and the debt ratio are positively related, thereby supporting the substitution hypothesis. On the other hand, Asquith and Mullins [1] support the price pressure hypothesis, as there is no statistically significant relationship between the two variables when the size of SEOs is controlled.

The third category is the signaling hypothesis proposed by Leland and Pyle [14]. If there is information asymmetry between investors and the manager, the investors observe the decisions made by the manager, who has more information, in order to obtain information about the firm [15]. For example, the decision to undertake an SEO is a signal to reduce managerial stock ownership for investors, which serves as an unfavorable factor in the stock market. Moreover, the increase of agency costs due to reduced managerial stock ownership might have a negative impact on the stock market [8]. Meanwhile, Rangan [5] reports that firms that level up profits by increasing discretionary accruals before SEOs end up facing a bigger fall of stock price in the long run, and points out that earnings management before the announcement of SEOs provides the wrong information to investors. In summary, prior research suggests that SEOs have a negative impact on stock prices.

The fourth category is the investment opportunities hypothesis proposed by McConnell and Muscarrella [16], modified from the signaling hypothesis. A manager considers SEOs only when financing with debts is insufficient. Therefore, SEOs indicate that there is an investment opportunity that guarantees sufficient profitability despite its subsequent disadvantages. Thus, SEOs are considered positive information about sustainable development in future performance, thereby serving as a favorable factor in the stock market. Yoon [6] uses the investment opportunities hypothesis to explain that the announcement of SEOs in Korea is accepted favorably in the short term. Yoon [6] sets the old shareholder forfeiture rate at the point of SEOs as a proxy for the excellence of investment opportunities, and claims that the positive excess return for two days after the announcement shows a positive relationship with the power loss rate. Myers and Majluf [7] support the investment opportunities hypothesis, claiming that new stocks are issued when the expected future cash flows are big enough even after reflecting the negative effects of rights issues, whereas bonds are issued on contrary prospects. Moreover, Chung and Jeong [17] report that stock price rather went up after SEOs if information asymmetry is relatively low. Yoon [18] reports that there is a statistically significant and positive excess earning rate on the day of the announcement for issuers after the abolition of the market price discount issuance system, but that rate does not show a statistically significant correlation with future operating performance of the issuers. Yoon [18] thereby claims that the investment opportunities hypothesis is not supported.

The fifth category is the old shareholder interest hypothesis. In the US, the wealth of old shareholders can be transferred to a third party if new stocks are issued by public offering. However, if new stocks are issued with a market price discount in the allotment of old shareholders, as in Korea, the benefit relevant to the discounted amount belongs to old shareholders, thereby serving as a favorable factor in the short term [8]. However, in the case of preferred dividend of employee stock ownership association, the wealth transfer of old shareholders serves as an unfavorable factor [8]. The market price discount issuance system applying various discount rates is implemented up until 1990 in Korea, but, since 1991, it has become completely liberalized, and, thus, the effect cannot be anticipated.

Loughran and Ritter [4] analyze long-term stock returns of 3702 companies that issued SEOs from 1970 to 1990, and report that stock returns of those who invested in issuers are $15 \%$ for three years and 
$33.4 \%$ for five years depending on the holding period, but the stock returns of those who invested in non-issuers are $48 \%$ for three years and $92.8 \%$ for five years. This indicates that the returns from the issuers are lower by 33 percentage points for three years and 59.4 percentage points for five years. Moreover, Spiess and Affleck-Graves [19] compared the stock returns of firms organized by matching the stock returns of SEO issuers from 1975 to 1989 with industry and firm size, and produced similar results to those of Loughran and Ritter [4].

According to previous studies that analyze SEO issuers from 1987 to 1998 in the Korean market [18,20,21], there is a statistically significant and negative excess earning rate for 1-3 years after SEOs, and stock returns fall even more as time passed.

When we review recent research, interesting evidence related to performance of firms after SEOs.

Using SEOs in India, Deb [22] finds that declining equity performance is mainly due to the deterioration in operating performance after such an issue. Furthermore, firms with more available free cash flows and greater perceived growth opportunities show higher declines. Deb [22] concludes that Indian firms tend to time the market and engage in value-destroying activities.

However, Dutta [23] examines whether underperformance following Australian SEOs does not hold when the definition of 'long-run' or the methods to measure the abnormal returns are changed. The empirical analysis reveals that the underperformance of Australian SEOs is highly significant when the BHAR (Buy-and-Hold Abnormal Return) method is employed. However, these underperformances tend to disappear using value-weighted by market capitalization. Using on the evidence, authors argue that the long-run underperformance of Australian SEOs is sensitive to the methods used to measure the abnormal performance.

Interestingly, Johnson et al. [24] study the effects of SOEs on the issuers' partners. Because the partners might have the financial dependence of the issuers, the consequences of SOEs affect on not only issuers but also partners (supply chains). Our results are largely consistent with the customer revelation hypothesis. We hypothesize that SEOs reveal adverse information about an issuer's major customers and find that issuers and their large customers experience negative returns on SEOs announcements. These results are more pronounced when customers have higher levels of information asymmetry and when customer-supplier relationships are particularly important. Large customers of issuers experience larger declines sales, operating performance in post-SEOs, and credit ratings than large customers of non-issuers. In addition, SEO issuer sales to large customers and relationship duration significantly decline.

Walker et al. [25] find that the announcement return associated with an SEOs is relatively greater when the SEOs is preceded by issuers whose purpose of SEOs is investment. This suggests that firms state their intention to invest the proceeds of SEOs build credibility with the market, allaying possible agency concerns.

Yang et al. [26] report that financial constraints and financial distress risk lead firms to report greater earnings around SEOs and report different performance in the long run. Authors show that earnings managing firms with financial constraints perform well, but high distress risk firms perform poorly after SEOs. These results suggest that financially constrained firms signal their post-issue profitability releasing information of operational inflexibility, while those with high distress risk inflate earnings to benefit from raised capital.

Young and $\mathrm{Wu}$ [27] study the effects of firms' pre-issue investment levels and changes in institutional ownership on their long-run performance after SEOs. They find that the under-investing and over-investing firms are likely to underperform and that changes in institutional ownership before SEOs positively relate to firms' long-run performance.

In summary, previous studies have reported negative excess earning rates for 1-5 years after SEOs, and stock returns become even lower as time passes. Moreover, long-term operating performance after SEOs declines compared to before, and even more as time passed. The long-term fall of stock price and operating performance has a statistically significant and positive correlation. 
Previous studies provide various causes for stock price response before and after SEOs. For example, there is a high correlation between the negative price earnings ratio in the stock market after SEOs and rights issue size based on the price pressure hypothesis [1], debt ratio by the substitution hypothesis [2,3], and discretionary accrual before SEOs [5]. There is a correlation between the positive price earnings ratio before and after SEOs and the old shareholder forfeiture rate based on the investment opportunities hypothesis [6], stock price compared to intrinsic value [7], and market price discount rate by the old shareholder interest hypothesis [8,9]. Market conditions at the point of rights issue [12] and data environment of rights issuers [17] are correlated with stock returns after SEOs.

However, these studies conducted only partial analysis, not comprehensive analysis, on SEOs and stock price response. In particular, there is insufficient empirical research on long-term stock prices and operating performance after SEOs. Therefore, this study analyzes whether operational structure change, in addition to the causes identified by previous studies, can explain the long-term fall of stock prices and operating performance after SEOs.

Operational structure change is an inevitable process of sustainable development. Firms attempt to change their operational structure with the resources they secure from SEOs. For example, they attempt to incorporate diversification strategies, such as new plant and equipment investments, expansion of their current fields of operation, and entry into new fields. However, considerable amounts of time and cost are required in the process of building a new operational structure. Thus, operating performance during that period is likely to be lower than that before. This phenomenon has appeared in previous research about corporate diversification and mergers [28]. Furthermore, performance due to operational structure change appears after stock price formation, which results in the decline of stock price after SEOs. However, such low operating performance and under-performance in stock returns is a temporary phenomenon, and, if a new operational structure is developed, there will be high operating performance in the long term, which is likely to be perceived as a favorable factor in the stock market, according to the investment opportunities hypothesis.

Similarly, there is evidence that diversification tends to have higher firm performance at the beginning of the investment. The firms with diversification have greater returns and cost savings from sharing and transferring asset and capabilities from economies of scope (Chari et al. [29]). In addition, Kuppswamy and Villalonga [30], and Hann et al. [31] show operational structure change measured by related or unrelated diversification increase the value of firms, and have lower cost of capital.

Therefore, this study sets the following hypotheses based on previous studies and operational structure change.

Hypothesis 1. There is a positive correlation between operational structure change and long-term operating performance after SEOs.

Hypothesis 2. There is a positive correlation between operational structure change and long-term stock returns after SEOs.

Operational structure change in these two hypotheses is measured by the level of corporate diversification and the size of plant and equipment investment. The level of corporate diversification is measured by the Berry-Herfindahl index(see Appendix B for the implication of index), which uses the number of operating segments and the ratio of sales of each operating segment out of total sales. Klein and Lien [32] claims that empirical studies of diversification tend to conflate the effects of diversification and organizational complexity, and organizational complexity can be measured by segment counts in industry. Klein and Lien [32] predicts that after SEOs, increased capitals could be used to change operational structures of rights offering firms and that one of the changes in operational structure would be found in diversification strategy so that we use the methods in Comment and Jarrell [33] and Jin [34], the number of segments, and revenue based the Berry-Herfindahl index. In general, the Berry-Herfindahl index indicates the market concentration of the industry, but, in this study, it is 
used to determine the degree of diversification of the business in which firms enter the business. The size of plant and equipment investment is measured by net investment in plant and equipment.

Hypothesis 1 verifies whether operational structure change explains the long-term operating performance after SEOs even when reflecting the explanatory factors proposed by previous studies (e.g., rights issue size, debt ratio decrease, and earnings management size).

Hypothesis 2 verifies whether operational structure change explains the long-term stock returns after SEOs even when reflecting the explanatory factors proposed by previous studies (e.g., return on equity level, return on equity change, and excess earning rate in the past year before SEOs).

\section{Materials and Methods}

\subsection{Research Methodology}

\subsubsection{Empirical Model of Operating Performance}

The following regression model in Equation (1) is developed to verify Hypothesis 1:

$$
\Delta R O A_{i, s t}=\alpha_{0}+\beta_{1} \times \Delta O P C H_{i, s t}+\beta_{2} \times T A C_{i, s}+\beta_{3} \times M T B_{i, s}+\beta_{4} \times \Delta \text { Sales }_{i, s}+\Sigma \text { Dummies }+\varepsilon
$$

where

$\Delta R O A_{i, s t}=$ the change rate of operating performance for firm $i$, from year $s$ to year $t$,

(1) $\Delta R O A_{i, 01}=\frac{\left(R O A_{i, 1}-R O A_{i, 0}\right)}{R O A_{i, 0}}$, (2) $\Delta R O A_{i, 02}=\frac{\left(R O A_{i, 2}-R O A_{i, 0}\right)}{R O A_{i, 0}}$, (3) $\Delta R O A_{i, 03}=\frac{\left(R O A_{i, 3}-R O A_{i, 0}\right)}{R O A_{i, 0}}$,

$\triangle O P C H_{i, s t}=$ the change rate of operational structure firm $i$, from year $s$ to year $t$,

(1) $\Delta N_{-} S e g_{i, s t}=$ the change rate of the number of operating segments of firm $i$, from year $s$ to year $t$,

(2) $\Delta B H I_{i, s t}=$ the change rate of the Berry-Herfindahl index by operating segment sales of firm $i$, from year $s$ to year $t=\left[\left\{1-\sum_{j=1}^{j}\left(\frac{\text { Sales }_{i, j, j}}{\text { Sale }_{i, t}}\right)^{2}\right\}-\left\{1-\sum_{j=1}^{j}\left(\frac{\text { Sales }_{i, j, j}}{\text { Sales }_{i, s}}\right)^{2}\right\}\right]$, Sales $i_{i, t, j}=$ segment $j$ sales for firm $i$ in year $t$, Sales ${ }_{i, t}=$ total sales for firm $i$ in year $t$;

(3) $\Delta C a p_{-} E x p_{i, s t}=$ the change rate of capital expenditure for firm $i$, from year $s$ to year $t=$

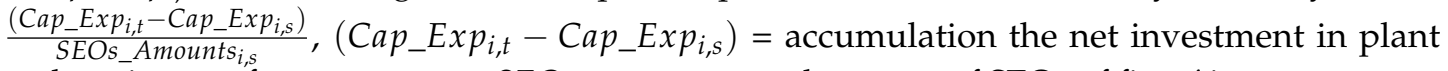
and equipment from year $s$ to $t, S E O s_{\text {Amounts }_{i, s}}=$ total amount of SEOs of firm $i$ in year $s$;

$T A C_{i, s}=$ total accrual of firm $i$ in year $s=\frac{\left(\text { Net income }_{i, s}-\text { Operating } \text { cash }_{\text {flow }}, s\right)}{\text { Average total asset } t_{, s}} ;$

$M T B_{i, s}=$ market-to-book ratio of firm $i$ in year $s=\frac{\text { Market value of Equity } y_{i, s}}{\text { Book value of Equity } y_{i, s}}$

$\Delta$ Sales $_{i, s}=$ sales growth rate of firm $i$ in year $s=\frac{\left(\text { Sales }_{i, s}-\text { Sales }_{i, s-1}\right)}{\text { Sales }_{i, s-1}} ;$

$\Sigma$ Dummies = year dummy, industry dummy.

We establish Model (1), using total accruals and sales growth and growth opportunity from Cohen and Zarowin [35] and Rangan [5]. Operating performance, which is the dependent variable, is the unexpected return on assets by deducting $s$ year return on assets from $t$ year return on assets. The level of corporate diversification and plant and equipment investment are key explanatory variables to verify Hypothesis 1 . This study used $T A C_{i, s}, M T B_{i, s}$, and $\Delta$ Sales $_{i, s}$ as control variables affecting operating performance.

Operational structure change is measured by the level of corporate diversification and plant and equipment investment. The level of corporate diversification is measured using the following two 
indexes [33]. The first is the change in the number of operating segments $\left(\Delta N_{-} S e g_{i, s t}\right)$. The second is the change in the Berry-Herfindahl index based on sales $\left(\Delta B H I_{i, s t}\right)$. This is the sum of sales that are first divided according to each operating segment by total sales and squared. The Berry-Herfindahl index is a typical method used to measure the level of corporate diversification. If there is one operating segment, $B H I_{i, s t}$ has the value of 1 , and a higher level of corporate diversification results in convergence to 0 . For convenience of interpretation, the Berry-Herfindahl index is deducted from 1 so that higher corporate diversification indicates the value closer to 1 . Plant and equipment investment $\left(\triangle C a p \_E x p_{i, s t}\right)$ is calculated by accumulating the net investment in plant and equipment (=increase of plant asset decrease of plant asset) from year $s$ to $t$, and dividing it by the amount of SEOs in year $s$.

The process of building a new operational structure with the resources secured from SEOs requires a considerable amount of time and cost. Thus, the operating performance during that period is likely to be lower than before. However, this low operating performance is a temporary phenomenon in the process of building a new operational structure, and once the new structure is established, there might be high operating performance in the long term. Therefore, the signs of the coefficients of $\Delta N \_S e g_{i, s t}$, $\triangle B H I_{i, s t}$ and $\triangle$ Cap_Exp $p_{i, s t}$ are not as predicted.

$T A C_{i, s}$ is total accrual in year $s$, and this amount has lower durability than cash flows; thus, profits in the next term are lower if the performance of the current term is adjusted according to the accounting choices made by the manager [4]. Therefore, the bigger the amount of the total accrual, the lower the operating performance is expected to be in the next term. $M T B_{i, s}$ is the measure of investment opportunities or growth, and, thus, the higher it is, the higher the operating performance is expected to be in the next term. $\Delta$ Sales $_{i, S}$ is the sales growth rate, and the higher the growth rate in the current term is, the higher the future operating performance is expected to be. $\Sigma$ Dummies represents year and industry dummies.

\subsubsection{Empirical Model of Abnormal Return}

The following regression model Equation (2) is developed to verify Hypothesis 2:

$$
\begin{aligned}
& \text { BAHR }_{i, s t}=\alpha_{0}+\beta_{1} \times \triangle O P C H_{i, s t}+\beta_{2} \times \text { Num_Issue }_{i, s}+\beta_{3} \times \Delta \text { Debt }_{i, s t}+\beta_{4} \times \text { Forfeiture }_{i, s} \\
& +\beta_{5} \times \text { Discount }_{i, s}+\Sigma \text { Controls }+\Sigma \text { Dummies }+\varepsilon,
\end{aligned}
$$

where

$B A H R_{i, s t}=$ buy-and-hold returns for firm $i$, from year $s$ to year $t$;

Num_Issue $i_{i, s}=$ the number of outstanding shares at SEO for firm $i$ in year $s$;

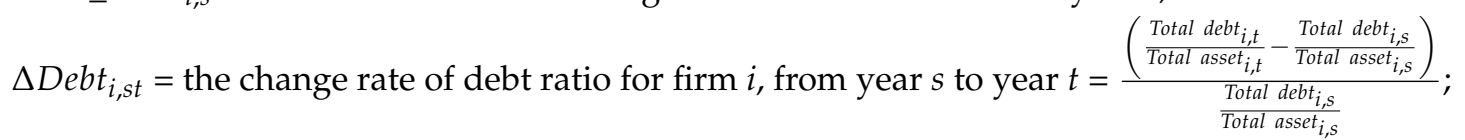

Forfeiture $_{i, s}=$ old shareholder forfeiture rate at seasoned equity offering for firm $i$ in year $s$;

Discount $_{i, s}=$ market discount rate at seasoned equity offering for firm $i$ in year $s$;

$\Sigma$ Controls $=\triangle R O A_{i, s t}, T A C_{i, s}, M_{T} B_{i, s}, \Delta$ Sales $_{i, s}$ in Equation (1);

Other variables are as defined for Equation (1).

Following the models in Loughran and Ritter [4] and Rangan [5], we put operational structure change variables in Model (2), along with other key variables from prior research such as number of outstanding shares (Scholes [11]), debt ratio (Asquith and Mullins), old shareholders' forfeiture rates(Leland and Pyle [14]; Yoon [6]), and discount rate (Jung [8]). We use control variables that might affect stock returns such as sales growth and market-to-book ratio, total accruals, and return on assets. Monthly earnings rates are measured and accumulated from April year $s$ to March year $t$ to measure the stock performance after SEOs. The level of corporate diversification and plant and equipment investment in Equation (2) are key explanatory variables to verify Hypothesis 2. The process of changing to a new operational structure with the resources secured from SEOs requires a considerable 
amount of time and cost. Thus, the operating performance during that period is likely to be lower than before. Since the performance due to operational structure change appears after the point of stock formation, stock prices fall after SEOs. However, this fall of stock returns is a temporary phenomenon, and it might be perceived as a favorable factor in the stock market according to the investment opportunities hypothesis. Therefore, the signs of the coefficients of $\Delta N_{-} S e g_{i, s t}, \Delta B H I_{i, s t}$ and $\triangle$ Cap_Exp $p_{i, s t}$ are not as predicted.

This study implements the variables presented in previous studies as control variables in order to determine whether operational structure change can explain operating performance and stock price after SEOs. The size of stock issuance at the point of SEOs (Num_Issue $i_{i, s}$ ) is a variable to test the price pressure hypothesis proposed by Scholes [10], and the increase of stock supply leads to the fall of that stock price in the long run; thus, the bigger the rights issue size is, the more likely there is to be a fall of stock prices [1,24].

The increase rate of debt ratio $\left(\Delta D e b t_{i, s t}\right)$ is based on the substitution hypothesis proposed by Galai and Masulis [13]. If the debt ratio decreases owing to SEOs, existing creditors receive higher interest at lower risks. Therefore, the decrease of debt ratio according to SEOs results in the transfer of the wealth of existing shareholders to creditors. Thus, a higher debt ratio leads to lower stock returns.

The old shareholder forfeiture rate at the point of SEOs (Forfeiture $e_{i, s}$ ) is to test the old shareholder interest hypothesis. According to Yoon [6], a higher old shareholder forfeiture rate leads to greater loss of old shareholders due to SEOs. Therefore, to make up for the loss, there must be higher net present value of new investments. Issuing an SEO means that the net present value of investment might bring profits even after making up for the loss of shareholders, and, thus, there is a positive correlation between the old shareholder forfeiture rate and the excess returns.

The market price discount rate at the point of SEOs (Discount $t_{i, s}$ ) is based on Jung [8] and Shin [9]. SEOs by the shareholder allotment method do not affect stock prices in the US, but they are perceived as a negative signal in Korea because of the market price discount rate, which is one of the institutional characteristics of SEOs in Korea. Therefore, there is evidence that if the stock split effect accompanied by excessive market price discount rate is controlled in Korea, SEOs might result in a fall of stock prices, as in the US.

\subsection{Sample Selection}

Samples used in this study are non-financial firms listed on the KOSPI and KOSDAQ from 1997 to 2011 with a financial year-end at the end of December. SEOs in the financial sector are excluded because they are likely to be issued according to external or non-financial decisions, such as government regulations, instead of financial decisions [9,21]. This paper does not consider samples that have experienced operational structure change without SEOs because SEOs' decision is beyond the scope of this study.

Data on SEOs are collected using the Korea Listed Companies Association database (TS-2000). The following samples are excluded from the first data extracted. First, third-party allotment is eliminated because it is decided by a policy factor [21], and has low profitability and stock price and, thus, is mostly used when it is impossible to issue general SEOs or there is a need for equity participation of those in a special relationship with the firm, such as the government, joint ventures, or clients, which is differentiated from general SEOs. In particular, SEOs through third-party allotment are in many cases abused by marginal firms to avoid being kicked out of the market, as a means to finance the acquisition of managerial rights, and for expedient investments, rather than being used for their original purposes, such as implementing new technology of normal businesses, improving financial structure, and attracting foreign capital [35,36].

Second, small amounts less than 1 billion KRW are excluded. If the amount is less than 1 billion $\mathrm{KRW}$, the firm is not subject to submit a registration statement. Moreover, this is mainly used by firms facing difficulties in financing from other sources owing to their weak financial structure, thereby possibly resulting in benefits for long-term stock returns after SEOs. 
Third, firms that issued SEOs within three years of listing are excluded in order to avoid the fall of returns of the first stocks in public offering, as suggested by Kim and Byun [37]. For the same reason, the samples excluded the cases in which there are SEOs in the succeeding three years of issuing SEOs in order to eliminate their interdependency [38]. The following are the reasons of this sample condition [10]. First, this condition can avoid serious dependence of statistical tests (e.g., multiple SEOs conducted by one firm can have the same explanatory variables in regressions). Second, firms with frequent SEOs are likely to have high growth or potential financial problems. Including such firms may yield biased inferences since their performance comes from other reasons (e.g., certain hot industries) rather than SEOs. Therefore, the number of samples in our study is relatively small compared to previous literature.

Data on stock prices, stock returns, and financial data are collected using KIS-VALUE provided by NICE Information Service Co., Ltd (Seoul, South Korea). The total number of samples is 286.

\subsection{Descriptive Statistics}

Table 1 shows the basic statistics of variables used in this study. The amount of funds financed through SEOs (SEOs_Amount $i, s$ ) is 30 billion KRW on average, and 680 billion KRW at maximum. $\triangle R O A_{i, 01}$ is $(-) 1 \%, \triangle R O A_{i, 02}$ is $2 \%$, and $\triangle R O A_{i, 03}$ is $1 \%$. This result is different from previous studies claiming that long-term operating performance falls after SEOs. $B A H R_{i, 1}$ is $(-) 3 \%, B A H R_{i, 12}$ is $11 \%$, and $B A H R_{i, 13}$ is $7 \%$, showing no long-term under-performance.

Table 1. Descriptive statistics.

\begin{tabular}{|c|c|c|c|c|c|c|c|}
\hline Variables & Mean & Std. Dev. & Minimum & 1st Quartile & Median & 3rd Quartile & Maximum \\
\hline SEOs_Amount $_{i, s}$ & 30.39 & 88.96 & 1.10 & 5.18 & 9.66 & 19.00 & 680.64 \\
\hline$\Delta R O A_{i, 01}$ & -0.01 & 0.25 & -2.65 & -0.04 & -0.01 & 0.03 & 1.25 \\
\hline$\Delta R O A_{i, 02}$ & 0.02 & 0.23 & -1.74 & -0.04 & 0.00 & 0.06 & 1.23 \\
\hline$\Delta R O A_{i, 03}$ & 0.01 & 0.23 & -1.64 & -0.05 & 0.00 & 0.07 & 1.33 \\
\hline$B A H R_{i, 1}$ & -0.03 & 0.54 & -0.87 & -0.40 & -0.12 & 0.19 & 2.38 \\
\hline$B A H R_{i, 12}$ & 0.11 & 0.84 & -0.93 & -0.50 & -0.11 & 0.41 & 3.12 \\
\hline$B A H R_{i, 13}$ & 0.08 & 0.99 & -0.94 & -0.58 & -0.19 & 0.40 & 4.64 \\
\hline$\Delta N \_S e g_{i, 01}$ & 0.38 & 1.00 & -0.60 & 0.00 & 0.00 & 0.25 & 4.00 \\
\hline$\Delta N \_S e g_{i, 02}$ & 0.52 & 1.53 & -0.67 & 0.00 & 0.00 & 0.33 & 9.00 \\
\hline$\Delta N \_S e g i, 03$ & 0.31 & 0.89 & -0.67 & 0.00 & 0.00 & 0.33 & 4.00 \\
\hline$\Delta \bar{B} H I_{i, 01}$ & -0.04 & 0.41 & -1.00 & -0.20 & -0.03 & 0.08 & 1.90 \\
\hline$\Delta B H I_{i, 02}$ & 0.02 & 0.49 & -0.79 & -0.23 & -0.01 & 0.16 & 2.27 \\
\hline$\Delta B H I_{i, 03}$ & 0.07 & 0.56 & -0.70 & -0.28 & 0.00 & 0.26 & 2.15 \\
\hline$\Delta C a p_{2} E_{x p} p_{i, 01}$ & 0.95 & 1.73 & -2.32 & 0.10 & 0.40 & 1.21 & 9.66 \\
\hline$\Delta$ Cap_Exp & 1.40 & 2.66 & -3.77 & 0.15 & 0.63 & 1.66 & 14.43 \\
\hline$\Delta C a p \_E x p$ & 1.92 & 3.53 & -3.72 & 0.16 & 0.80 & 2.51 & 19.52 \\
\hline$T A C_{i, s}$ & -0.04 & 0.14 & -0.72 & -0.10 & -0.02 & 0.05 & 0.28 \\
\hline Num_Issue ${ }_{i, s}$ & 14.85 & 1.25 & 11.56 & 14.17 & 14.89 & 15.70 & 18.68 \\
\hline$\Delta \operatorname{Debt}_{i, 01}$ & 0.13 & 0.62 & -0.64 & -0.08 & 0.02 & 0.15 & 4.67 \\
\hline$\Delta D e b t_{i, 02}$ & 0.13 & 0.55 & -0.80 & -0.10 & 0.03 & 0.19 & 3.76 \\
\hline$\Delta D e b t_{i, 03}$ & 0.13 & 0.59 & -0.84 & -0.15 & 0.04 & 0.24 & 3.35 \\
\hline Forfeiture $_{i, s}$ & 0.01 & 0.04 & 0.00 & 0.00 & 0.00 & 0.00 & 0.31 \\
\hline Discount $_{i, s}$ & 17.68 & 13.70 & 0.00 & 0.00 & 25.00 & 30.00 & 50.00 \\
\hline$M T B_{i, s}$ & 1.59 & 1.86 & 0.09 & 0.64 & 1.11 & 1.82 & 14.55 \\
\hline$\Delta$ Sales $_{i, s}$ & 0.21 & 0.95 & -0.83 & -0.05 & 0.10 & 0.28 & 14.53 \\
\hline
\end{tabular}

Note: (1) See Appendix A for the definition of variables; (2) To control for outliers in the sample, all the variables are winsorized for the upper and lower $1 \%$.

$\Delta N \_S e g_{i, 01}$ is $38 \%, \Delta N \_S_{e g}, 02$ is $52 \%$, and $\Delta N \_\operatorname{Seg}_{i, 03}$ is $31 \%$. $\Delta B H I_{i, 01}$ is $(-) 4 \%, \Delta B H I_{i, 02}$ is $2 \%$, and $\triangle B H I_{i, 03}$ is $7 \%$, showing an increase. $\triangle$ Cap_Expi,01 increased to $95 \%, \Delta C_{a} p_{-} \operatorname{Exp}_{i, 02}$ to $140 \%$, and $\triangle$ Cap_Expi,03 to as high as $192 \%$. 
On the other hand, the debt ratio due to SEOs $\left(\Delta D e b t_{i, s t}\right)$ did not decrease, which suggests that SEOs and debt issuance are carried out at the same time. The market-to-book value $\left(M T B_{i, s}\right)$ is 1.59 on average. The sales growth rate of SEO issuers $\left(\Delta\right.$ Sales $\left._{i, s}\right)$ is on average $21 \%$, and the maximum is $1453 \%$.

\section{Results of Multi-Regression Analysis}

Tables 2-4 show the empirical analysis results for Hypothesis 1 . Table 2 shows the correlation between operating performance $\left(\triangle R O A_{i, 01}\right)$ and operational structure change one year after SEOs. Operational structure change is measured by the level of corporate diversification and plant and equipment investment. Model (1) used $\Delta S e g_{i, 01}$ as the first corporate diversification variable. The coefficient of $\Delta S e g_{i, 01}$ is statistically significant and negative at (-)0.042. This implies that the operating performance immediately after SEOs is lower because of the investment that occurred in the process of building a new operational structure through corporate diversification. The coefficients of $\triangle B H I_{i, 01}$, which is the second measurement variable of corporate diversification, and of $\Delta C a p_{-} E x p_{i, 01}$, which is the measure of plant and equipment investment coefficient, turn out not to be significant. Model (4), which considers all values of operational structure change, shows that the coefficient of $\Delta S e g_{i, 01}$ is statistically significant and negative, thereby implying that operational structure change due to the increase of operating segments has a negative correlation with the operating performance of the current term.

Table 2. Operating performance analysis at one year after SEOs.

\begin{tabular}{|c|c|c|c|c|c|c|c|c|c|}
\hline \multicolumn{10}{|c|}{$\Delta R O A_{i, s t}(s=0, t=1)=\alpha_{0}+\beta_{1} \cdot \Delta O P C H_{i, s t}+\beta_{2} \cdot T A C_{i, s}+\beta_{3} \cdot M T B_{i, s}+\beta_{4} \cdot \Delta$ Sales $_{i, s}+\Sigma$ dummies $+\varepsilon$} \\
\hline \multicolumn{2}{|c|}{ Variables } & \multicolumn{2}{|c|}{ Model (1) } & \multicolumn{2}{|c|}{ Model (2) } & \multicolumn{2}{|c|}{ Model (3) } & \multicolumn{2}{|c|}{ Model (4) } \\
\hline \multirow{3}{*}{$\triangle O P C H_{i, 01}$} & $\Delta S e g_{i, 01}$ & -0.042 & $(-2.53)$ & - & - & - & - & $-\underset{* *}{-0.048}$ & $(-2.51)$ \\
\hline & $\Delta B H I_{i, 01}$ & - & - & 0.024 & $(0.64)$ & - & - & -0.028 & $(-0.65)$ \\
\hline & $\Delta$ Cap_Exp $p_{i, 01}$ & - & - & - & - & 0.004 & $(0.45)$ & 0.002 & $(0.27)$ \\
\hline \multicolumn{2}{|c|}{$\mathrm{TAC}_{i, 0}$} & $-\underset{* * *}{-0.600}$ & $(-5.81)$ & $-\underset{* * *}{-0.603}$ & $(-5.76)$ & $-\underset{* * *}{-0.612}$ & $(-5.85)$ & -0.607 & $(-5.83)$ \\
\hline \multicolumn{2}{|c|}{$M T B_{i, 0}$} & $0.018^{* *}$ & $(2.32)$ & $0.016^{* *}$ & $(2.07)$ & $0.017^{* *}$ & $(2.15)$ & $0.018^{* *}$ & (2.39) \\
\hline \multirow{2}{*}{\multicolumn{2}{|c|}{$\begin{array}{l}\Delta \text { Sales }_{i, 0} \\
\text { F-value }\end{array}$}} & $0.032 * *$ & $(2.06)$ & $0.032 * *$ & $(2.02)$ & $0.031 *$ & $(1.96)$ & 0.031 ** & (1.98) \\
\hline & & \multicolumn{2}{|c|}{$3.61 * * *$} & \multicolumn{2}{|c|}{$3.31^{* * *}$} & \multicolumn{2}{|c|}{$3.30^{* * *}$} & \multicolumn{2}{|c|}{$3.36^{* * *}$} \\
\hline \multicolumn{2}{|c|}{ Adjusted $R^{2}$} & \multicolumn{2}{|c|}{0.198} & \multicolumn{2}{|c|}{0.180} & \multicolumn{2}{|c|}{0.179} & \multicolumn{2}{|c|}{0.194} \\
\hline \multicolumn{2}{|c|}{ \# of obs. } & \multicolumn{2}{|c|}{286} & \multicolumn{2}{|c|}{286} & \multicolumn{2}{|c|}{286} & \multicolumn{2}{|c|}{286} \\
\hline
\end{tabular}

Note: $(1)^{* * *}, * *$, and $*$ denote statistical significance at the $1 \%, 5 \%$, and $10 \%$ levels, respectively; (2) $t$-values are specified in parentheses; (3) For brevity, intercept, year and industry dummies are not reported; (4) See Appendix A for the definition of variables.

Table 3. Operating performance analysis at two years after SEOs.

\begin{tabular}{|c|c|c|c|c|c|c|c|c|c|}
\hline \multicolumn{10}{|c|}{$\Delta R O A_{i, s t}(s=0, t=2)=\alpha_{0}+\beta_{1} \cdot \Delta O P C H_{i, s t}+\beta_{2} \cdot T A C_{i, s}+\beta_{3} \cdot M T B_{i, s}+\beta_{4} \cdot \Delta$ Sales $_{i, s}+\Sigma$ Dummies $+\varepsilon$} \\
\hline \multicolumn{2}{|c|}{ Variables } & \multicolumn{2}{|c|}{ Model (1) } & \multicolumn{2}{|c|}{ Model (2) } & \multicolumn{2}{|c|}{ Model (3) } & \multicolumn{2}{|c|}{ Model (4) } \\
\hline & $\Delta \operatorname{Seg}_{\mathrm{i}, 02}$ & $0.027^{* *}$ & $(2.51)$ & - & - & - & - & $0.033 * * *$ & $(2.89)$ \\
\hline$\triangle O P C H_{i, 02}$ & $\Delta B H I_{i, 02}$ & - & - & 0.017 & $(0.56)$ & - & - & 0.048 & $(1.52)$ \\
\hline & $\Delta$ Cap_Exp $p_{i, 02}$ & - & - & - & - & -0.004 & $(-0.87)$ & -0.005 & $(-0.94)$ \\
\hline \multicolumn{2}{|c|}{$\mathrm{TAC}_{i, 0}$} & $\begin{array}{c}-0.707 \\
* * *\end{array}$ & $(-7.50)$ & $-\underset{* * *}{-0.692}$ & $(-7.24)$ & $-\underset{* * *}{-0.692}$ & $(-7.27)$ & $\begin{array}{l}-0.697 \\
* * *\end{array}$ & $(-7.39)$ \\
\hline \multirow{2}{*}{\multicolumn{2}{|c|}{$\begin{array}{c}\text { MTB }_{i, 0} \\
\Delta \text { Sales }_{i 0}\end{array}$}} & 0.005 & $(0.67)$ & 0.005 & $(0.66)$ & 0.004 & (0.59) & 0.004 & $(0.53)$ \\
\hline & & $0.026^{*}$ & $(1.80)$ & $0.029 * *$ & $(2.00)$ & $0.028^{* *}$ & $(1.97)$ & $0.027 *$ & $(1.91)$ \\
\hline \multicolumn{2}{|c|}{ F-value } & \multicolumn{2}{|c|}{$3.79 * * *$} & \multicolumn{2}{|c|}{$3.49^{* * *}$} & \multicolumn{2}{|c|}{$3.51^{* * *}$} & \multicolumn{2}{|c|}{$3.65^{* * *}$} \\
\hline \multirow{2}{*}{\multicolumn{2}{|c|}{ Adjusted $R^{2}$}} & \multicolumn{2}{|c|}{0.209} & \multicolumn{2}{|c|}{0.191} & \multicolumn{2}{|c|}{0.192} & \multicolumn{2}{|c|}{0.213} \\
\hline & & \multicolumn{2}{|c|}{286} & \multicolumn{2}{|c|}{286} & \multicolumn{2}{|c|}{286} & \multicolumn{2}{|c|}{286} \\
\hline
\end{tabular}

Note: $(1)^{* * *}, * *$, and * denote statistical significance at the $1 \%, 5 \%$, and $10 \%$ levels, respectively; (2) $t$-values are specified in parentheses; (3) For brevity, intercept, year and industry dummies are not reported; (4) See Appendix A for the definition of variables. 
Table 4. Operating performance analysis at three years after SEOs.

\begin{tabular}{|c|c|c|c|c|c|c|c|c|c|}
\hline \multicolumn{10}{|c|}{$\Delta R O A_{i, s t}(s=0, t=3)=\alpha_{0}+\beta_{1} \cdot \Delta O P C H_{i, s t}+\beta_{2} \cdot T A C_{i, s}+\beta_{3} \cdot M T B_{i, s}+\beta_{4} \cdot \Delta$ Sales $_{i, s}+\Sigma$ Dummies $+\varepsilon$} \\
\hline \multicolumn{2}{|c|}{ Variables } & \multicolumn{2}{|c|}{ Model (1) } & \multicolumn{2}{|c|}{ Model (2) } & \multicolumn{2}{|c|}{ Model (3) } & \multicolumn{2}{|c|}{ Model (4) } \\
\hline \multirow{3}{*}{$\triangle O P C H_{i, 03}$} & $\Delta \operatorname{Seg}_{\mathrm{i}, 03}$ & 0.001 & $(0.04)$ & - & - & - & - & 0.016 & $(0.78)$ \\
\hline & $\triangle B H I_{i, 03}$ & - & - & $0.043 *$ & $(1.73)$ & - & - & $0.052 *$ & $(1.90)$ \\
\hline & $\Delta C a p_{-} \operatorname{Exp}_{i, 03}$ & - & - & - & - & 0.000 & $(-0.09)$ & -0.001 & $(-0.18)$ \\
\hline \multicolumn{2}{|c|}{$T A C_{i, 0}$} & $-\underset{* * *}{0.495}$ & $(-5.04)$ & $-\underset{* * *}{-0.488}$ & $(-5.01)$ & $-\underset{* * *}{-0.494}$ & $(-5.04)$ & $\underset{* * *}{-0.488}$ & $(-4.98)$ \\
\hline \multirow{2}{*}{\multicolumn{2}{|c|}{$\begin{array}{c}\text { MTB }_{i, 0} \\
\Delta \text { Sales }_{i 0}\end{array}$}} & 0.012 & (1.63) & 0.011 & $(1.56)$ & 0.012 & $(1.62)$ & 0.010 & $(1.45)$ \\
\hline & & 0.015 & $(1.02)$ & 0.015 & $(1.04)$ & 0.015 & $(1.02)$ & 0.015 & $(1.02)$ \\
\hline \multicolumn{2}{|c|}{ F-value } & \multicolumn{2}{|c|}{$1.92 * * *$} & \multicolumn{2}{|c|}{$2.05^{* * *}$} & \multicolumn{2}{|c|}{$1.92 * * *$} & \multicolumn{2}{|c|}{$1.92 * * *$} \\
\hline \multicolumn{2}{|c|}{ Adjusted $R^{2}$} & \multicolumn{2}{|c|}{0.080} & \multicolumn{2}{|c|}{0.091} & \multicolumn{2}{|c|}{0.080} & \multicolumn{2}{|c|}{0.086} \\
\hline \multicolumn{2}{|c|}{ \# of obs. } & \multicolumn{2}{|c|}{286} & \multicolumn{2}{|c|}{286} & \multicolumn{2}{|c|}{286} & \multicolumn{2}{|c|}{286} \\
\hline
\end{tabular}

Note: $(1)^{* * *}, * *$, and $*$ denote statistical significance at the $1 \%, 5 \%$, and $10 \%$ levels, respectively; (2) $t$-values are specified in parentheses; (3) For brevity, intercept, year and industry dummies are not reported; (4) See Appendix A for the definition of variables.

As proved by previous studies, the coefficient of $T A C_{i, 0}$ is statistically significant and negative, whereas the coefficients of $M T B_{i, 0}$ and $\triangle$ Sales $_{i, 0}$ are statistically significant and positive.

Table 3 shows the correlation between operating performance $\left(\triangle R O A_{i, 02}\right)$ and operational structure change two years after SEOs. Contrary to the results in Table 2, the coefficient of $\Delta S e g_{i, 02}$ in Model (1) is statistically significant and positive at 0.027 . Model (4), which considers all values of operational structure change, shows that only the coefficient of $\Delta S e g_{i, 02}$ is statistically significant and positive. This implies that operational structure change through SEOs is positively correlated with long-term operating performance, especially in terms of corporate diversification.

Like Table 3, Table 4 also shows that operational structure change and long-term operating performance has a statistically significant and positive correlation. The coefficient of $\triangle B H I_{i, 03}$ in Model (2) is statistically significant and positive at 0.043 . Model (4), which considers all values of operational structure change, also shows that the coefficient of $\triangle B H I_{i, 03}$ is statistically significant and positive.

Tables 5-7 show the empirical analysis results for Hypothesis 2. Table 5 shows the correlation between stock returns $\left(B A H R_{i, 01}\right)$ and operational structure change one year after SEOs. Models (1), (2), and (3), which individually use $\triangle S e g_{i, 01}, \triangle B H I_{i, 01}, \Delta C a p_{-} \operatorname{Exp}_{i, 01}$, all show values that are not significant. However, Model (4), which considers all values of operational structure change, shows that the coefficient of $\triangle B H I_{i, 01}$ is statistically significant and negative at (-)0.164. This implies that there is under-performance in stock returns in terms of operational structure change.

Table 5. Stock return analysis at one year after SEOs.

\begin{tabular}{|c|c|c|c|c|c|c|c|c|c|}
\hline \multicolumn{10}{|c|}{$\begin{array}{c}\text { BAHR }_{i, s t}(s=0, t=1)=\alpha_{0}+\beta_{1} \cdot \Delta O P C H_{i, s t}+\beta_{2} \cdot \text { Num_Issue }_{i, s}+\beta_{3} \cdot \Delta \text { Debt }_{i, s t}+\beta_{4} \cdot \text { Forfeiture }_{i, s}+\beta_{5} \cdot \text { Discount }_{i, s} \\
+\Sigma \text { Controls }+\Sigma \text { Dummies }+\varepsilon\end{array}$} \\
\hline \multicolumn{2}{|c|}{ Variables } & \multicolumn{2}{|c|}{ Model (1) } & \multicolumn{2}{|c|}{ Model (2) } & \multicolumn{2}{|c|}{ Model (3) } & \multicolumn{2}{|c|}{ Model (4) } \\
\hline & $\Delta \operatorname{Seg}_{i, 01}$ & -0.013 & $(-0.35)$ & - & - & - & - & -0.044 & $(-1.07)$ \\
\hline$\triangle O P C H_{i, 01}$ & $\Delta B H I_{i, 01}^{\prime}$ & - & - & -0.116 & $(-1.45)$ & - & - & -0.164 * & $(-1.80)$ \\
\hline & $\Delta C a p \_E x p_{i, 01}$ & - & - & - & - & 0.029 & $(1.55)$ & 0.027 & $(1.48)$ \\
\hline \multicolumn{2}{|c|}{ Num_Issue $e_{i, 1}$} & -0.020 & $(-0.78)$ & -0.023 & $(-0.91)$ & -0.012 & $(-0.46)$ & -0.019 & $(-0.71)$ \\
\hline \multicolumn{2}{|c|}{$\Delta D^{2} b t_{i, 01}$} & 0.072 & $(1.30)$ & 0.073 & $(1.33)$ & 0.062 & $(1.13)$ & 0.067 & $(1.21)$ \\
\hline \multicolumn{2}{|c|}{ Forfeiture $_{i, 0}$} & $1.749^{* *}$ & $(2.20)$ & 1.600 ** & $(2.02)$ & $1.795^{* *}$ & $(2.28)$ & $1.725^{* *}$ & (2.18) \\
\hline \multirow{2}{*}{\multicolumn{2}{|c|}{$\begin{array}{l}\text { Discount } \\
\text { F-value }\end{array}$}} & 0.003 & $(0.93)$ & 0.003 & (1.09) & 0.003 & $(0.85)$ & 0.003 & $(1.02)$ \\
\hline & & \multicolumn{2}{|c|}{$3.02 * * *$} & \multicolumn{2}{|c|}{$3.10^{* * *}$} & \multicolumn{2}{|c|}{$3.12 * * *$} & \multicolumn{2}{|c|}{$3.04^{* * *}$} \\
\hline \multicolumn{2}{|c|}{ Adjusted $R^{2}$} & \multicolumn{2}{|c|}{0.185} & \multicolumn{2}{|c|}{0.191} & \multicolumn{2}{|c|}{0.192} & \multicolumn{2}{|c|}{0.196} \\
\hline \multicolumn{2}{|c|}{ \# of obs. } & \multicolumn{2}{|c|}{286} & \multicolumn{2}{|c|}{286} & \multicolumn{2}{|c|}{286} & \multicolumn{2}{|c|}{286} \\
\hline
\end{tabular}

Note: $(1){ }^{* * *}, * *$, and $*$ denote statistical significance at the $1 \%, 5 \%$, and $10 \%$ levels, respectively; (2) $t$-values are specified in parentheses; (3) For brevity, intercept, control variables, year and industry dummies are not reported; (4) See Appendix A for the definition of variables. 
Table 6. Stock return analysis at two years after SEOs.

\begin{tabular}{|c|c|c|c|c|c|c|c|c|c|}
\hline \multicolumn{10}{|c|}{$\begin{array}{c}\operatorname{BAHR}_{i, s t}(s=0, t=2)=\alpha_{0}+\beta_{1} \cdot \Delta O P C H_{i, s t}+\beta_{2} \cdot N_{u m} \text { Issue }_{i, s}+\beta_{3} \cdot \Delta \text { Debt }_{i, s t}+\beta_{4} \cdot \text { Forfeiture }_{i, s}+\beta_{5} \cdot \text { Discount }_{i, s} \\
+\Sigma \text { Controls }+\Sigma \text { Dummies }+\varepsilon\end{array}$} \\
\hline \multicolumn{2}{|c|}{ Variables } & \multicolumn{2}{|c|}{ Model (1) } & \multicolumn{2}{|c|}{ Model (2) } & \multicolumn{2}{|c|}{ Model (3) } & \multicolumn{2}{|c|}{ Model (4) } \\
\hline & $\Delta S e g_{i, 02}$ & -0.052 & $(-1.32)$ & - & - & - & - & -0.051 & $(-1.21)$ \\
\hline$\triangle O P C H_{i, 02}$ & $\Delta B H I_{i, 02}$ & - & - & 0.063 & $(0.58)$ & - & - & 0.014 & $(0.12)$ \\
\hline & $\Delta C a p \_E x p_{i, 02}$ & - & - & - & - & 0.015 & $(0.80)$ & 0.015 & $(0.81)$ \\
\hline \multicolumn{2}{|c|}{ Num_Issue $e_{i, 0}$} & -0.038 & $(-0.98)$ & -0.036 & $(-0.91)$ & -0.032 & $(-0.80)$ & -0.032 & $(-0.80)$ \\
\hline \multicolumn{2}{|c|}{$\Delta D_{e b t_{i, 02}}$} & -0.072 & $(-0.82)$ & -0.078 & $(-0.88)$ & -0.085 & $(-0.96)$ & -0.078 & $(-0.88)$ \\
\hline \multicolumn{2}{|c|}{ Forfeiture $_{i, 0}$} & -0.257 & $(-0.21)$ & -0.317 & $(-0.25)$ & -0.280 & $(-0.22)$ & -0.199 & $(-0.16)$ \\
\hline \multirow{2}{*}{\multicolumn{2}{|c|}{$\begin{array}{l}\text { Discount } \\
\text { F-value }\end{array}$}} & $0.010 * *$ & $(2.23)$ & $0.011^{* *}$ & $(2.25)$ & 0.010 ** & $(2.19)$ & $0.010 * *$ & $(2.12)$ \\
\hline & & \multicolumn{2}{|c|}{$3.42 * * *$} & \multicolumn{2}{|c|}{$3.36^{* * *}$} & \multicolumn{2}{|c|}{$3.37 * * *$} & \multicolumn{2}{|c|}{$3.22 * * *$} \\
\hline \multicolumn{2}{|c|}{ Adjusted $R^{2}$} & \multicolumn{2}{|c|}{0.214} & \multicolumn{2}{|c|}{0.210} & \multicolumn{2}{|c|}{0.210} & \multicolumn{2}{|c|}{0.210} \\
\hline \multicolumn{2}{|c|}{ \# of obs. } & \multicolumn{2}{|c|}{286} & \multicolumn{2}{|c|}{286} & \multicolumn{2}{|c|}{286} & \multicolumn{2}{|c|}{286} \\
\hline
\end{tabular}

Note: $(1)^{* * *}, * *$, and ${ }^{*}$ denote statistical significance at the $1 \%, 5 \%$, and $10 \%$ levels, respectively; (2) $t$-values are specified in parentheses; (3) For brevity, intercept, control variables, year and industry dummies are not reported; (4) See Appendix A for the definition of variables.

Table 7. Stock return analysis at three years after SEOs.

\begin{tabular}{|c|c|c|c|c|c|c|c|c|c|}
\hline \multicolumn{10}{|c|}{$\begin{array}{c}\text { BAHR }_{i, s t}(s=0, t=3)=\alpha_{0}+\beta_{1} \cdot \Delta O P C H_{i, s t}+\beta_{2} \cdot \text { Num_Issue }_{i, s}+\beta_{3} \cdot \Delta \text { Debt }_{i, s t}+\beta_{4} \cdot \text { Forfeiture }_{i, s}+\beta_{5} \cdot \text { Discount }_{i, s} \\
+\Sigma \text { Controls }+\Sigma \text { Dummies }+\varepsilon\end{array}$} \\
\hline \multicolumn{2}{|c|}{ Variables } & \multicolumn{2}{|c|}{ Model (1) } & \multicolumn{2}{|c|}{ Model (2) } & \multicolumn{2}{|c|}{ Model (3) } & \multicolumn{2}{|c|}{ Model (4) } \\
\hline & $\Delta S e g_{i, 03}$ & -0.014 & $(-0.18)$ & - & - & - & - & 0.054 & $(0.65)$ \\
\hline$\triangle O P C H_{i, 03}$ & $\Delta B H I_{i, 03}$ & - & - & 0.213 ** & $(2.01)$ & - & - & $0.227^{* *}$ & $(2.01)$ \\
\hline & $\Delta C a p \_\operatorname{Exp}_{i, 03}$ & - & - & - & - & $0.062 * * *$ & $(3.76)$ & $0.060^{* * *}$ & $(3.68)$ \\
\hline \multicolumn{2}{|c|}{ Num_Issue $_{i, 0}$} & -0.059 & $(-1.24)$ & -0.056 & $(-1.19)$ & -0.021 & $(-0.45)$ & -0.018 & $(-0.38)$ \\
\hline \multicolumn{2}{|c|}{$\Delta \operatorname{Debt}_{i, 03}$} & -0.119 & $(-1.17)$ & -0.103 & $(-1.01)$ & -0.151 & $(-1.52)$ & -0.132 & $(-1.32)$ \\
\hline \multicolumn{2}{|c|}{ Forfeiture $_{i, 0}$} & -2.136 & $(-1.45)$ & -2.022 & $(-1.39)$ & -1.594 & $(-1.11)$ & -1.456 & $(-1.01)$ \\
\hline \multirow{2}{*}{\multicolumn{2}{|c|}{$\begin{array}{l}\text { Discount } \\
\text { F-value }\end{array}$}} & 0.006 & $(1.10)$ & 0.006 & $(1.07)$ & 0.004 & $(0.70)$ & 0.004 & $(0.65)$ \\
\hline & & \multicolumn{2}{|c|}{$2.7^{* * *}$} & \multicolumn{2}{|c|}{$2.86^{* * *}$} & \multicolumn{2}{|c|}{$3.29 * * *$} & \multicolumn{2}{|c|}{$3.24 * * *$} \\
\hline \multicolumn{2}{|c|}{ Adjusted $R^{2}$} & \multicolumn{2}{|c|}{0.160} & \multicolumn{2}{|c|}{0.173} & \multicolumn{2}{|c|}{0.204} & \multicolumn{2}{|c|}{0.211} \\
\hline \multicolumn{2}{|c|}{ \# of obs. } & \multicolumn{2}{|c|}{286} & \multicolumn{2}{|c|}{286} & \multicolumn{2}{|c|}{286} & \multicolumn{2}{|c|}{286} \\
\hline
\end{tabular}

Note: $(1)^{* * *, * *}$, and $*$ denote statistical significance at the $1 \%, 5 \%$, and $10 \%$ levels, respectively; (2) $t$-values are specified in parentheses; (3) For brevity, intercept, control variables, year and industry dummies are not reported; (4) See Appendix A for the definition of the variables.

Table 6 shows the correlation between stock returns $\left(B A H R_{i, 02}\right)$ and operational structure change two years after SEOs. Similar to Table 5, the correlation between operational structure change and stock returns is not significant in Models (1), (2), and (3). In particular, Model (4), which considers all values of operational structure change, shows no significant correlation between operational structure change and stock returns.

Table 7 shows the correlation between stock returns $\left(B A H R_{i, 03}\right)$ and operational structure change three years after SEOs. $\triangle B H I_{i, 03}$ in Model (2) has a statistically significant and positive correlation with stock returns, and Cap_Exp $p_{i, 03}$ in Model (3) has a statistically significant and positive correlation with stock returns. Therefore, the correlation between operational structure change and stock returns is not formed when SEOs are issued, but appears afterward.

\section{Discussion}

Tables 2-4, which present the empirical analysis results for Hypothesis 1, can be summarized as follows. The process of building a new operational structure with the resources secured from SEOs requires considerable amounts of time and cost. The results of the empirical analysis show that the correlation between operational structure and operating performance changes from statistically significant and negative one year after SEOs to statistically significant and positive two and three years after SEOs. This supports the investment opportunities hypothesis-that low operating performance is a temporary phenomenon in the process of building a new operational structure, and, once it is 
developed, there will be high operating performance in the long term. Therefore, Hypothesis 1 is supported, and operational structure change for sustainable development has a statistically significant and positive correlation with long-term operating performance. Among the control variables, $T A C_{i, 0}$ is the major cause of adverse effects on operating performance after SEOs.

Tables 5-7, which present the empirical analysis results for Hypothesis 2, can be summarized as follows. Operational structure change $\left(\triangle B H I_{i, 01}\right)$ in the model of stock returns ( $\left.B A H R_{i, s t}\right)$ shows a statistically significant and negative correlation with stock returns after one year, while operational structure change shows no significant correlation with stock returns after two years. However, the coefficients of $\triangle B H I_{i, 03}$ and $\triangle C_{a p} E_{x p} p_{i, 03}$ are statistically significant and positive in the analysis after three years. This indicates that some time must pass before operational structure change increases operating performance. Furthermore, disclosed accounting information is actually information from the past in principle, and, thus, economic benefits of the current term are reflected in stock prices but might not be reflected in the financial statements. In other words, time must pass before plant and equipment investment after SEOs leads to operating performance. Thus, in the results, there is no significant stock price response at first, and the operating performance in the next term is perceived as a favorable factor after three years. In summary, there is a time lag in the stock market regarding operational structure change.

When it comes to the interpretation of operational structure change, the operational structure change consists of related $\left(\mathrm{A}, \mathrm{B}, \mathrm{C} \rightarrow \mathrm{A}, \mathrm{A}^{\prime}, \mathrm{B}, \mathrm{C}\right)$, unrelated $(\mathrm{A}, \mathrm{B}, \mathrm{C} \rightarrow \mathrm{A}, \mathrm{B}, \mathrm{C}, \mathrm{D})$ diversification, vertical (A, B, C $\rightarrow$ A (B is lower tier), $C$ ), and horizontal $(A, B, C \rightarrow A+B+C)$ integration. As the Berry-Herfindahl index, a proxy for operational structure change, is measured by only segments and each of their sales, it is possible to differ from the actual operational structure change. Thus, this study does not interpret the type of operational structure change. Inability of testing horizontal or vertical integration, and related or unrelated diversification is a limitation of this paper. In addition, we do not match standard industrial classification codes to each segments, because it also might incur measurement error by our discretionary categorization.

The results for control variables can be interpreted as follows. The rights issue size (Num_Issue $i_{i, 0}$ ) is negatively correlated with stock returns, but this is not significant. Therefore, the price pressure hypothesis proposed by Scholes [11] is not supported. The increased rate of debt $\left(\Delta D e b t_{i, s t}\right)$ had a negative or positive correlation, depending on the model, but none is significant. Therefore, the substitution hypothesis proposed by Galai and Masulis [13] is not supported. The old shareholder forfeiture rate (Forfeiture ${ }_{i, 0}$ ) showed a statistically significant and positive correlation with the stock returns in all models for one year after SEOs, thereby supporting the old shareholder interest hypothesis. The market price discount rate (Discount ${ }_{i, 0}$ ) showed a statistically significant and positive correlation with stock returns only two years after SEOs.

\section{Conclusions}

Previous studies have identified various causes of stock returns before and after SEOs. However, they have conducted only partial analyses, not comprehensive analyses, on SEOs and stock returns. In particular, there is insufficient empirical research on long-term stock price and operating performance after SEOs. This study investigates whether there is sustainability in operational structure and the effects of sustainable development on operational performance and the market.

The results are as follows. First, change in corporate diversification has a statistically significant and negative correlation with operating performance one year after SEOs. However, the increased rate of the number of operating segments increases two years after SEOs, and the increase of the Berry-Herfindahl index using the sales of operating segments has a statistically significant and positive correlation with operating performance after three years. This result shows that corporate diversification decreases operating performance in the short term but increases operating performance in the long term, thereby supporting the hypothesis that operational structure change through SEOs might increase performance. 
Second, plant and equipment investment does not show a statistically significant correlation with stock returns for two years after SEOs. However, it shows a statistically significant and positive correlation with stock returns for three years after SEOs, which indicates that time must pass for operating performance to increase by operational structure change. In other words, since some time is required until plant and equipment investment after SEO results in operating performance, there is no significant stock price response in the first two years, and only after three years is the favorable factor of operating performance in the next term reflected in stock prices.

We acknowledge that unknown measurement errors or other correlated omitted variables could influence our empirical findings. Our analysis is based on publicly available data, which is machine-readable. In order to analyze the difference between vertical or horizontal integration in operational structure, further studies need the detailed information from business reports.

Despite these caveats, this study contributes to the literature in the following ways. This study complements a large body of literature that investigates the positive consequences of sustainable development from operational structure using SEOs. We also provide evidence of sustainable development mechanisms, such as the increasing ratio of operational segments, leads to a favorable stock market reaction by rebuilding operational structure using SEOs. Lastly, we analyze operating performance after SEOs according to operational structure change while including all causes presented by previous studies. Future studies could be extended to the comparison of financing type, for which the firms decided to issue SEO or bonds for sustainability strategies and consequences.

Author Contributions: Chihyoun Ahn collected machine readable data, brought the empirical model based on literature review, and analyzed the data. Mi-Ok Kim designed the hypothesis, summarized literature review and wrote the paper. Hyung-Rok Jung conceived and designed the paper and hypothesis, contributed to set the empirical model, and wrote the paper.

Conflicts of Interest: The authors declare no conflict of interest.

\section{Appendix A}

Table A1. The Definition of Variables.

\begin{tabular}{|c|c|}
\hline Variables & Definition \\
\hline$\Delta R O A_{i, s t}$ & $\begin{array}{l}\text { the change rate of operating performance for firm } i \text {, from year } s \text { to year } t \text {, } \\
\text { (1) } \Delta R O A_{i, 01}=\frac{\left(R O A_{i, 1}-R O A_{i, 0}\right)}{R O A_{i, 0}} \\
\text { (2) } \Delta R O A_{i, 02}=\frac{\left(R O A_{i, 2}-R O A_{i, 0}\right)}{R O A_{i, 0}} \\
\text { (3) } \Delta R O A_{i, 03}=\frac{\left(R O A_{i, 3}-R O A_{i, 0}\right)}{R O A_{i, 0}}\end{array}$ \\
\hline$\triangle O P C H_{i, s t}$ & $\begin{array}{l}\text { the change rate of operational structure firm } i \text {, from year } s \text { to year } t \text {, } \\
\text { (1) } \Delta N_{-} \text {Seg }_{i, s t}=\text { the change rate of the number of operating segments of firm } i \text {, from year } s \\
\text { to year } t \text {, } \\
\text { (2) } \Delta B H I_{i, s t}=\text { the change rate of the Berry-Herfindahl index by operating segment sales of } \\
\text { firm } i \text {, from year } s \text { to year } t \\
=\left[\left\{1-\sum_{j=1}^{j}\left(\frac{\text { Sales }_{i, t, j}}{\text { Sales }_{i, t}}\right)^{2}\right\}-\left\{1-\sum_{j=1}^{j}\left(\frac{\text { Sales }_{i, j, j}}{\text { Sales }_{i, s}}\right)^{2}\right\}\right] \\
\text { Sales }{ }_{i, t, j}=\text { segment } j \text { sales for firm } i \text { in year } t, \\
\text { Sales } s_{i, t}=\text { total sales for firm } i \text { in year } t \text {, } \\
\text { (3) } \Delta \text { Cap_Exp } p_{i, s t}=\text { the change rate of capital expenditure for firm } i \text {, from year } s \text { to year } t= \\
\left.\text { (Cap_Exp } p_{i, t}-\text { Cap_Exp }_{i, s}\right) \\
\text { SEOs_Amounts } s_{i, s} \\
\text { (Cap_Exp } \\
\text { from year } s \text { to } t=\text { (increase of plant asset }- \text { decrease of plant asset) from year } s \text { to } t \text {, } \\
\text { SEOs_Amounts } s_{i, s}=\text { total amount of SEOs of firm } i \text { in year } s \text {. }\end{array}$ \\
\hline
\end{tabular}


Table A1. Cont.

\begin{tabular}{|c|c|}
\hline Variables & Definition \\
\hline$T A C_{i, s}$ & $\begin{array}{l}\text { total accrual of firm } i \text { in year } s= \\
\frac{\left(\text { Net income }_{i, s}-\text { Operating cash } \text { flow }_{i, s}\right)}{\text { Average total asset }} \text { i,s }\end{array}$ \\
\hline$M T B_{i, t}$ & $\begin{array}{l}\text { market-to-book ratio of firm } i \text { in year } s \\
=\frac{\text { Market value of Equity }}{\text { Book value of Equity } y_{i, s}}\end{array}$ \\
\hline$\Delta$ Sales $_{i, s}$ & $\begin{array}{l}\text { sales growth rate of firm } i \text { in year } s \\
=\frac{\left(\text { Sales }_{i, s}-\text { Sales }_{i, s-1}\right)}{\text { Sales }_{i, s-1}}\end{array}$ \\
\hline$B A H R_{i, s t}$ & buy-and-hold returns for firm $i$, from year $s$ to year $t$ \\
\hline Num_Issue $e_{i, s}$ & the number of outstanding shares at SEO for firm $i$ in year $s$ \\
\hline$\Delta D e b t_{i, s t}$ & 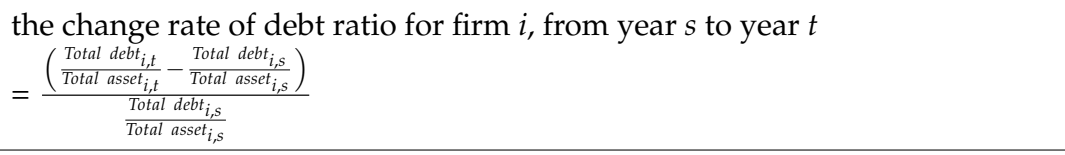 \\
\hline Forfeiture $_{i, s}$ & old shareholder forfeiture rate at seasoned equity offering for firm $i$ in year $s$ \\
\hline Discount $_{i, s}$ & market discount rate at seasoned equity offering for firm $i$ in year $s$ \\
\hline$\Sigma$ Controls & $\Delta R O A_{i, s t}, T A C_{i, s t}, M T B_{i, s t}, \Delta$ Sales $_{i, s t}$ \\
\hline$\Sigma$ Dummies & year dummy, industry dummy \\
\hline
\end{tabular}

\section{Appendix B. The Implication of the Berry-Herfindahl Index (BHI)}

The extent of firm diversification depends on the number of products or services provided by a firm and their relative weight in the firm's total output. Berry [39] has derived the index as an application of the Herfindahl index of concentration. The Berry-Herfindahl index of firm diversification is constrained to lie between 0 and 1 , and is increasing in product diversification, so that the larger the number of products produced by the firm, the higher the index and the greater the degree of inequality in the product mix, the lower the index. In the case of a uni-product firm, the index would be equal to zero; in the case of a multi-product firm with production spread evenly over a very large number of products, the index would approach 1 . In principle, the index should be calculated by using individual product sales data, but since individual products sales data is not available, the index in our paper is calculated using segments' sales data.

For example, based on Samsung Electronics (Seoul, South Korea) segments' sales data, the BHI is $1-\left(0.1471^{2}+0.3820^{2}+0.2427^{2}+0.2332^{2}+0.005^{2}\right)=0.7191$, which means the higher the score of BHI is the higher the level of diversification is.

Table A2. Numerical example for BHI.

\begin{tabular}{cc}
\hline The Segments of Samsung Electronics in 2009 & Sales Ratio \\
\hline Television, Monitor, Refrigerator, Washing Machine, Air Conditioner, Medical Devices, etc. & $14.71 \%$ \\
HandHeld Player, Network System, Computer, etc. & $38.20 \%$ \\
DRAM (Dynamic Random-Access Memory), NAND (Not AND) Flash, M-AP (Mobile & \\
Application Processor), TFT-LCD (Thin Film Transistor Liquid Crystal Display), & $24.27 \%$ \\
OLED (Organic Light Emitting Diodes), etc. & $23.32 \%$ \\
Head units, Infotainment, Telematics, Speaker, etc. & $0.50 \%$ \\
Others & $100.00 \%$ \\
\hline
\end{tabular}

\section{References}

1. Asquith, P.; Mullins, D.W. Equity issues and offering dilution. J. Financ. Econ. 1986, 15, 61-89. [CrossRef] 
2. Bhagat, S.; Frost, P.A. Issuing costs to existing shareholders in competitive and negotiated underwritten public utility equity offerings. J. Financ. Econ. 1986, 15, 233-259. [CrossRef]

3. Masulis, R.W.; Korwar, A.N. Seasoned equity offerings: An empirical investigation. J. Financ. Econ. 1986, 15, 91-118. [CrossRef]

4. Loughran, T.; Ritter, J.R. The operating performance of firms conducting seasoned equity offerings. J. Financ. 1997, 52, 1823-1850. [CrossRef]

5. Rangan, S. Earnings management and the performance of seasoned equity offerings. J. Financ. Econ. 1998, 50, 101-122. [CrossRef]

6. Yoon, Y.K. CEO's seasoned equity offering decision making. Korean J. Financ. Assoc. 1996, 12, 77-105. (In Korean)

7. Myers, S.C.; Majluf, N.S. Corporate financing and investment decisions when firms have information that investors do not have. J. Financ. Econ. 1984, 13, 187-221. [CrossRef]

8. Jung, H.C. Value effect of seasoned equity offerings after controlling for stock splits. J. Financ. Bank. 1995, 1, 235-276. (In Korean)

9. Shin, Y.K. Announcement effects of seasoned equity offerings. Korean J. Financ. Manag. 1995, 12, 75-92. (In Korean)

10. Suzanne, B.; Dunphy, D.; Griffiths, A. Organizational Change for Corporate Sustainability, 3rd ed.; Routledge: London, UK, 2014.

11. Scholes, M.S. The market for securities: Substitution versus price pressure and the effects of information on share prices. J. Bus. 1972, 45, 179-211. [CrossRef]

12. Kang, H.S. The effect of the issue price in seasoned equity offerings on shareholders' wealth. Korean Manag. Rev. 1988, 18, 99-128. (In Korean)

13. Galai, D.; Masulis, R. The option pricing model and the risk factor of stock. J. Financ. Econ. 1976, 3, 53-81. [CrossRef]

14. Leland, H.; Pyle, D. Information asymmetries, financial structure, and financial intermediation. J. Financ. 1977, 32, 371-387. [CrossRef]

15. Ross, S.A. The determination of financial structure: The incentive-signaling approach. Bell J. Econ. 1977, 8 , 23-40. [CrossRef]

16. McConnell, J.J.; Muscarrella, C.J. Corporate capital expenditure decisions and the market value of the firm. J. Financ. Econ. 1985, 14, 399-422. [CrossRef]

17. Chung, H.C.; Jeong, Y.W. Seasoned equity offering announcement and market efficiency. Korean J. Financ. Manag. 2008, 25, 79-109. (In Korean)

18. Yoon, P.S. Short-term and long-term effect of seasoned equity offering. J. Korean Secur. Assoc. 1999, 25, 71-105. (In Korean)

19. Spiess, D.K.; Affleck-Graves, J. Under-performance in long-run stock returns following seasoned equity offerings. J. Financ. Econ. 1995, 38, 243-267. [CrossRef]

20. Kim, P.K.; Kong, M.J. Long-run abnormal stock returns and operating performance following seasoned equity offerings. Korean J. Financ. Manag. 2000, 17, 13-44. (In Korean)

21. Khil, J.W. Long-run performance in the seasoned equity issues. Hanyang J. Econ. Stud. 2001, 22, $261-283$. (In Korean)

22. Deb, S.G. Long-run performance of seasoned equity offerings. New evidence from India. Econ. Polit. Wkly. 2017, 52, 141-148.

23. Dutta, A. Seasoned equity offerings: Further evidence from Australia. Glob. Bus. Rev. 2017, 18, 1010-1018. [CrossRef]

24. Johnson, W.C.; Kang, J.K.; Masulis, R.W.; Yi, S. Seasoned equity offerings and customer-supplier relationships. J. Financ. Intermed. 2017. [CrossRef]

25. Walker, M.D.; Yost, K.; Zhao, J. Credibility and multiple SEOs: What happens when firms return to the capital market? Financ. Manag. 2016, 45, 675-703. [CrossRef]

26. Yang, T.H.; Hsu, J.; Yang, W.B. Firm's motives behind SEOs, earnings management, and performance. Int. Rev. Econ. Financ. 2016, 43, 160-169. [CrossRef]

27. Young, W.; Wu, C.C. Abnormal investment, changes in institutional ownership, and SEO long-run performance. Manag. Financ. 2017, 43, 842-864. [CrossRef] 
28. Mason, R.H.; Goudzwaard, M.B. Performance of conglomerate firms: A portfolio approach. J. Financ. 1976, 31, 39-48.

29. Chari, M.D.R.; Devaraj, S.; David, P. Research note: The impact of information technology investments and diversification strategies on firm performance. Manag. Sci. 2008, 54, 224-234. [CrossRef]

30. Kuppuswamy, V.; Villalonga, B. Does diversification create value in the presence of external financing constraints? evidence from the 2007-2009 financial crisis. Manag. Sci. 2016, 62, 905-923. [CrossRef]

31. Hann, R.; Ogneva, M.; Ozbas, O. Corporate diversification and the cost of capital. J. Financ. 2013, 68, 1961-1999. [CrossRef]

32. Klein, P.G.; Lien, L.B. Diversification, industry structure, and firm strategy: An organizational economics perspective. Adv. Strateg. Manag. 2009, 26, 289-312.

33. Comment, R.; Jarrell, G.A. Corporate focus and stock returns. J. Financ. Econ. 1995, 37, 67-87. [CrossRef]

34. Jin, S. The effect of conglomerate restructurings in late 1990's: Do size and diversification affect performance of Korean conglomerates. Korean J. Financ. Stud. 2003, 32, 219-254. (In Korean)

35. Cohen, D.A.; Zarowin, P. Accrual-based and real earnings management activities around seasoned equity offerings. J. Account. Econ. 2010, 50, 2-19. [CrossRef]

36. Kim, D.H.; Moon, S.J. A study on the improvement of capital increase through third-party allocation. J. Prof. Manag. 2010, 13, 75-91. (In Korean)

37. Kim, S.J.; Byun, H.S. Seasoned equity offering and long-run performance. Asian Rev. Financ. Res. 1998, 11, 23-49. (In Korean)

38. Kim, J.W. Earnings management using accruals and the long-run performance of SEOs. J. Bus. Res. 2013, 28, 165-191. (In Korean)

39. Berry, C.H. Corporate growth and diversification. J. Law Econ. 1971, 14, 371-383. [CrossRef]

(C) 2017 by the authors. Licensee MDPI, Basel, Switzerland. This article is an open access article distributed under the terms and conditions of the Creative Commons Attribution (CC BY) license (http:/ / creativecommons.org/licenses/by/4.0/). 